\title{
ANALYSIS OF ISLAMIC SPIRITUAL VALUES IN MATHEMATIC EDUCATION
}

\author{
Kusno \\ Muhammadiyah University of Purwokerto \\ Purwokerto, Indonesia \\ kusnoump@gmail.com
}

\begin{abstract}
The aim of this study was to analysis Islamic spiritual values in mathematic education on school based Islam. This was an introduction study of literature for finding relation between Islamic Spiritual values and mathematics values in mathematic education. This study discribed urgency of Islamic spiritual values on material, methode, and mathematic evaluation was integrated rationality and objectivity values, honesty, and integrity, with trancendental values reflected awareness as smart, critical, honesty, subject and obidient servant of Allah swt.
\end{abstract}

\section{Keywords : Islamic spiritual values, Mathematics values, integration, school based islam, trancendental}

\section{INTRODUCTION}

Acceleration of information flow of globalization causes interaction of cultures between nations to grow faster. At the same time there is a meeting between new values and old values that have been embraced by a community structure. One of the most inevitable waves in the era of globalization is the rapid influence of materialism, liberalism, secularism, capitalism and hedonism that has swept all facets of human life including education and culture in Indonesia. The world of education is facing various challenges, especially in the fields of culture, ethics and morals as a result of technological advances in the field of transportation and information (Rusniati, 2015: 109). In the field of culture understood materialism has influenced the orientation of human thinking in material glory alone, consequently not a few people who forget the ultimate life purpose. Secularism has distanced ethical, moral and spiritual values from science and technology. This is because science in western civilization is not built on revelations and religious beliefs, but is built on a cultural tradition with philosophical speculation that centers human beings as rational beings. As a result, science and ethical and moral values, governed by human ratios, are constantly changing. (Al-Attas, 1989: 5).

The notion of liberalism has made freedom of thought and acting freely, because it is oriented only towards western philosophy of the universal human model, the American and European human models who believe that (1) all human beings have equal potential in intellect, (2) both the natural order as well as social norms can be captured by reason, (3) man is otomistic and autonomous (Haryanto, 2014: 65). The notion of capitalism has influenced some of the practices of economic-based school management, resulting in the emergence of some elite schools at a high cost (especially in the private sector), the influence of hedonism has made fun and euphoria the life style of the nation. The influence of globalization, on the one hand, can make it easier for human to solve the problem, but on the other side can become bigger problem trigger that is just make split personality, person that is human separated between mind and soul, between intelligence and piety (Fanani, Sholihan \& Karnadi, 2014: 51).

In Islamic madrasahs or schools more specifically affiliated under pesantren (Islamic boarding school), the spiritual values of Islam should be the spirit or soul that moves all activities in order to achieve its vision and mission. Therefore, the vision, mission, goals and strategies of achieving spiritual values must be clear so that it can compose a series of targeted program activities. These values are integrated through the curriculum of education, which is taught to learners either directly through the lessons of religion and PPKn or indirectly through the exemplary of educators and educational and embeded with other learning materials including mathematics. It is intended that the spiritual values of Islam are more deeply materially and can develop simultaneously along with the cognitive development and skills of learners. The urgency of Islamic 
spiritual values integrated with mathematics education is that the process of reasoning runs simultaneously with the process of value internalization so as to build an essential awareness as it is supported by a rational basis of strong thinking. This is in accordance with what was proposed by Robert Einstein (1982: 8-9) that religion without science is blind and science without religion is paralyzed. Einstein's statement is very reasonable because religion was created to regulate man while mathematics is human activity itself, so there is a relationship between the spiritual values of religion, especially Islam as a religion rahmatan lil aalamiin with mathematic. However, in practice there is little systematic effort to integrate between the Islamic spiritual values in mathematics education even in Islamic schools. The systematic effort is how to realize the vision of the mission of Islamic spiritual values operatively in the syllabus and the plan of learning implementation (RPP) of mathematics so as to facilitate all parties, especially teachers to realize the learning of mathematics that requires students intelligently intellectually and spiritually.

The integration of the spiritual values of Islam in mathematics education is still rarely occupied, so far the cultivation of Islamic spiritual values with the values of mathematics run independently. The study of Islam that became the symbolic for the cultivation of spiritual values and Islamic teachings stood verbally and dogmatically (Rusdiana: 2014, p. 126) so it is less meaningful in life. Conversely, mathematics education that becomes the symbolic in the development of reason, communication, connection and problem solving to instill objective values, integrity, honesty and discipline is not built from the context of their life that is culturally based on Islam. Even often found in Islamic-based mathematics learning schools but not developed from the context of the Islamic world everyday students learn. The result happens meaningless because the information received is not connected to the cognitive structure that has been awakened from their daily culture.

Efforts to synergize between
mathematical intellectual reasoning with transcendental reason (spiritual Islam) in the world of education, especially mathematics education should be sought way out so that our nation will soon get Divine Grace and get out of the multi-dimensional crisis. Awareness among the Islam community began to rise with the establishment of integrated Islamic schools incorporated in the container of Integrated Islamic School Network (IISN). IISN has the vision of building a generation of intelligent and skilled Muslims through holistic education. The important issue experienced by Islamic schools is the difficulty of realizing a holistic education pattern that believes that an individual can discover the identity, meaning and purpose of life through its relationship with society, the natural environment, and spiritual values, or according to Miller (2005: 2) education that involves intellectual, emotional, physical, social, aesthetic, and spiritual work simultaneously. This is due, among other things, to the limited literature on integration models (Dinata, 2015: 168, Salafudin, 2015: 238) that elaborate the spiritual values of Islam in mathematics education. The limited source of information on the integration of Islamic spiritual values in mathematics education, both on the aspects of materials, methods, evaluation, teacher behavior, and the dimensions of mathematical ability became the main trigger of teacher difficulties in holistic mathematics learning.

The integration of Islamic spiritual values in mathematics education will give meaning to the achievement of vision and mission of Islamic school based. The spiritual values of Islam inherent in materials, methods, media, evaluation tools, and the behavior of teachers of mathematics is very important to be the inspiration of teachers in the realization of a holistic education. Teachers with all aspects of good thinking, emotional, insight, attitude and behavior and the decisions it takes should be the inspiration of students to be able to develop into the figure of generation of nation and generation of people with complete personality. At least teacher behavior becomes one of the supports in realizing the character education strengthening program (KDP). Because of the priority of national education (KDP PPK Team, 2017: 7-8), ie religious, nationalist, independent, integrity and mutual cooperation.

The founding fathers have placed spiritual values into the souls of the Indonesian nation that color the entire process of thinking and acting in the implementation of national education. Pancasila as the ideological foundation of the nation, excavated from the noble values of the Indonesian nation firmly recommends religious spiritual values in its first principle of "One Supreme Godhead". Further legislation sisdiknas no 20 year 2003 also firmly have interpreted education as conscious effort and planed to realize the atmosphere of learning and learning process so that learners actively develop their potential to have spiritual strength of religion, selfcontrol, personality, intelligence, noble character, as well as the necessary self-absorption, nation and state society. Spiritual values that are the soul in national education are expected to realize the personality of the noble nation of Indonesia and dignity. For that the formation of personality becomes one aspect of the purpose of education in all subjects including mathematics. 
P4TK Mathematics Kemendikbud (2011: 3 ) states that the purpose of learning mathematics in schools consists of goals that are formal and material objectives. Formal objectives are the logic of reasoning and the personal formation of learners, while the material objectives emphasize the problem solving and application of mathematics. In the formulation of formal objectives, the development of reason must be in line with the development of the personality of learners. This implies that mathematics education is built by integrating both the development of reason and personality simultaneously. As for the objective formulation of the material pressure to train the problem-solving skills in daily life associated with the application of mathematics. In general the formulation of mathematical objectives is to emphasize that the mathematics lessons are always associated with everyday life both that include reasoning and the formation of a whole person. The whole person is not only a subject with only intellectual intelligence, but also spiritual intelligence, emotional intelligence, and social intelligence. This means that the learning objectives of school mathematics recommend that the process of mathematization and internalization of values work in a balanced way.

\section{METHODS}

This study is a preliminary study using literature review method developed by the author based on experience in integrated learning in the school mathematics course.

\section{RESULTS AND DISCUSSION}

The spiritual values of Islam. Value in English, and valere in Latin, means price (Mulyana, 2011: 7). In the Great Dictionary of Indonesian Language (Purwadarminta, 1999: 677) value is defined as the properties that are important or useful for humanity. Spiritual according to Indonesian dictionary (Purwadarminta, 1999: 892) means something related to psychology (spiritual or inner). In this sense the spiritual values are the values associated with the psychic or spiritual person of a person who can enter and influence his life and be manifested in thought and behavior and in relation to one self, others, nature and God. Spiritual values are often called spirituality derived from the Latin word spiritus which means spirit, soul, spirit. From the Latin word is formed the French word is' spirit and the word la spiritualite. After this French word, we know the English word spirituality, (Harjana, 2009: 64) which in Indonesian becomes the word spirituality. Tanyi (2002: 500-509) states that spirituality is an inherent component of being human, and is subjective, intangible, multidimensional and involves the search for meaning in human life. Spirituality is a personal relationship that includes the individual's inner life, idealism, attitudes, thoughts, expectations and expresses his relationship with the transcendent figure in everyday life. Grine, Fares \& Mequellati (2015: 41) states that Islam views spirituality by linking actions in accordance with the fundamental purpose of human creation to worship Allah.

Furthermore Nashr (2008: 21-23) states that the spiritual values in a person is a spiritual force that encourages the person to act perfectly according to His will. Spiritual or spiritual values refer to what is related to the spirit world, to being in divine proximity, possessing naturalness and interiority. In spirituality, there is always the impression of the barakah, or the grace that flows in the veins of the Universe and in human life insofar as he dedicates himself to Him. Islamic spirituality is the realization of the attainment of Divine quality in his life embodied with respect and obedience only to His will. Spirituality in Islam is the realization of tauhid and based on awareness to Allah swt. (Aldarabah, Reham Almohtadi \& Khaled Mohamed, 2014: 69). Spirituality is also related to individual motivation (Giacalone, R; Jurkiewicz, C, 2003: 46) in searching for the meaning and purpose of his life. In other words, the spiritual can encourage individuals to live to be more meaningful, important, more ethical and sufficient. Spiritual value refers to the motivation of the individual to feel that every action is good and right based on what is believed. Thus the spiritual value of Islam underlies the individual to feel that good and right actions are based on divine truths that are reflected in the teachings of Islam.

The attainment of Islamic spiritual values in the individual involves all dimensions in man, namely the heart, the mind and the thought. The spiritual value of Islam within the individual as a foothold to be more universal in determining liferelated matters. The spiritual values of Islam lead individual to ethical behavior, true and honest because everything must be guided by the criteria of Allah swt. The spiritual values of Islam become strong controls for the individual to always submit to and obey the teachings of Islam which is believed to be the path of achieving glory. The internalization of the spiritual values of Islam in the individual leads to encouragement that every human activity should be valuable to Allah swt, so that the process of thinking and acting should be placed within the framework of worship or devotion of a servant to the Creator.

Huda \& Kartanegara (2015: 234) states that spiritual value has an important role as the foundation of the soul to be inculcated during the education process, the spiritual value is the value of 
the core character as the basis of a good individual character, to equip the human with quality and noble qualities. The importance of Islamic spiritual values in education (Motha, 2011: 59) is to help foster social relationships and live, life with gratitude, allowing wise use of wisdom, not only for personal gain but also for the benefit of those around him. The spiritual values of Islam can encourage learners to face increasingly complex challenges in their lives. Through the development of awareness and appreciation of the value of each individual in a diverse society, will lead to an attitude of responsibility to others. Learners will realize that the spiritual values of Islam are fundamental values for families and community structures at both local and global levels. Hamzah, Isa \& Janor (2010: 11) asserted that the spiritual values of Islam in education serve to bring humans closer to God, swt., and develop self-awareness of human responsibility as a khalifah. Spiritual values must be continuously developed in the learners so that it becomes a character that can bring life comfort for students and the surrounding environment.

In the perspective of tasawwuf Dalmeri \& Ratono (2016: 16) states that Islamic spirituality emphasizes the piety of the individual that produces personal satisfaction and meets the personal needs of the relationship with the Creator as the Beloved which will then proceed to God's creation, human and natural. In the perspective of sufism Islamic spirituality is a form of love for the Divine colored and conditioned by the knowledge and observance that has been practiced and contained in life. Spiritual consciousness in the perspective of Sufism according to Tulaeka (2012: 244) is expressed by the existence of a maqamat or spiritual stage consisting of eight levels of repentance, patience, zuhud, tawakkal, mahabbah, ridha and ma'rifat while according to Huda \& Kartanegara (2015: 231) Repentance, zuhud, patience, tawakal and tawadhu or ta'dzim.

From the description above can be affirmed that the spiritual values of Islam is a spiritual force or belief that encourages a person to fulfill Allah's will, as a manifestation of monotheism and a special relationship of a servant to him in adulthood, related to the consciousness of heart, mind and behavior blending with His majesty. The spiritual values of Islam as described above are substantively indicated by the existence of (1) the value of divine majesty (2) the presence of the Divine, (3) desire for the meaning of life, (4) self-existence as a servant of God (5) (6) union of the divine will.

Mathematical values. Mathematical values are values that are reflected in a mathematical activity. This mathematical activity is hereafter called school mathematics which Ebbutt and Straker in
Marsigit, (http://staffnew.uny.ac.id), are expressed as: (1) pattern and relationship tracing activities that require the investigation of patterns through various experiments, find sequences, differences, comparisons, groupings, understand and find relationships between concepts and draw conclusions, (2) creativity that requires imagination, intuition and discovery, which encourages learners to initiate, think differently, curiosity, ask, disprove, estimate, finding mathematical structures and designs, rewarding discovery, reflexive thinking by not suggesting the use of a particular method, (3) problem solving activities to stimulate, develop and solve math problems in its own way, help find information to solve math problems, encourage logical thinking, consistent, systematic and develop system documentation, help the use of media / props, (4) communication tools that encourage learners to recognize, create and explain examples of mathematical properties, provide reasons for the need for mathematical activities, reading, writing, respect for mathematics, and the mother tongue used in discussing mathematical problems accordingly with the context of learners. In the above activities are required rational and objective thinking and integrity attitude which is a manifestation of the values of the mathematical.

Widodo (2015) states that mathematics and mathematics education have a role in shaping the character of learner especially in logic or reasoning, upholding agreement (in definition), consistent, appreciate the process, creative, innovative, independent, and curiosity. The process of reasoning is made up of rational ways of thinking so as to reflect objective value. Upholding the agreement is formed from the process of defining concepts that involve elements of substance, characterization, and symbolization so as to reflect the value of integrity. Compliance is formed by the nature of its adherence to legally-verified theorems that reflect the value of honesty, consistency, and unity.

The urgency of Islamic spiritual values and mathematical values in mathematical education is an integral part of the educational development of the human character of Indonesia which is religious, humanist, intelligent, rational, objective and dignified. Education should directed to the effort to help learners mengijarif the purpose of creation as a servant and at the same time the khalifah of Allah on the surface of the earth. The birth of God-given consciousness and the attainment of God's Grace so that the birth of man's ability to meet (liqa ') with his Lord is the ultimate goal (Ahmad Rivauzi, 2007: 102). The values of divine majesty can be drawn from the mathematical symbols used, the regularities of the patterns, and the relation of concepts in a 
principle, for example to the sum of two dozens indicated by the Arabic numerals in the right palm and left us. From the palm of our hand is written 18 in Arabic letters and on the our left hand recorded number 81 with Arabic script. If both numbers are added then it will be obtained 99 which is called Asmaul Husna

To feel the presence of Divine in one's heart in order to internalize the spiritual values of Islam, can be done by interpreting a mathematical concept, for example in the concept of prime numbers defined as positive numbers whose factors 1 and self, can be interpreted that people who have The prime position (the most glorious) on the side of Allah swt is a person in whose heart there is the presence of Almighty Allah Almighty. To Him, man is obliged to submit, obey, and obey His commandments and stay away from His prohibitions. In other word, that mathematics is one of the means to imply the spiritual values of Islam as a form of kauniah verses. Mathematics can also be built from events whose terms with the spiritual meaning are taken from the Qur'an, the hadiths of the Prophet, and the life of the companions of the Prophet.

The spiritual values of Islam in mathematics education can be integrated through several strategies. Kusno (2013), there are four alternative strategies that can be used as an alternative to integrate the spiritual values of Islam in mathematics education, namely modeling, analogy, illustration and philosophy.

Modeling is a technique of character formation through a role model depicted in the story steam. Stories are powerful tools to hypnotize students 'reading interests to bring the students' minds into line with the roles depicted in them. The story content must be tailored to the psychological needs of learners, can touch emotionally, build the greatness of the soul, the requirement with spiritual values in a series of activities involving mathematical problems. In the modeling approach we need to select the characters in history, the stories of the prophets, the stories of the Companions, and other exemplary stories as freem work in the idea of spiritual values. In modeling can also be shown how the role model is able to resolve the moral pomegranate intelligently through mathematical solution, so that learners will admire the smart and good character. Modeling is a form of mathematical model that not only modeled mathematics into equality or inequality but also modeled the performance of a person for the good of the Islamic spiritual values he embraced. An example of a modeling approach with a role model of a goatslave slave to instill honesty, trustworthiness, fear to Allah, in order to realize his existence as a servant of Allah swt on a linear equation of one variable.
In a journey of Caliph Umar bin Khattab RA and his entourage, encountered a slave goat herd with a number of goats are very many, fat and nice. Then there was a dialogue between Umip and Umar with the shepherd as follows:

Caliph Umar: Fulan, the goats are many and very good, by chance I am with a group needing a goat for a travel allow?

Shepherd : I'm sorry sir, this is not my goat, I just pasture it and I've got the reward from the shepherding result.

Caliph Umar : Does your master know the number of goats?

Shepherd : No sir, all entrusted to me.

Caliph Umar: In order to test his faith, then the Caliph said "Well then coincidentally I bought one, and your master did not know"

Shepherd : Even if my master does not know, where is Allah SWT? Does not Allah see us at all times and circumstances.

Hearing the answer, Caliph Umar shed tears. He embraced the shepherd boy, then he asked that the shepherd boy deliver it to the master. After meeting with his employer, Caliph Umar then bid the price of the child. The agreement took place, and the shepherd boy was liberated by Caliph Umar. In addition, Caliph Umar also bought a number of goats that she pastored. The goats were then given to the shepherd boy, and became his full right, as a reward for the boy's honesty and trust.

a. Can you estimate how much it costs to free such slaves? Give the reason of your answer !. What is the price of an honesty with Allah SWT?

b. If the Caliph Umar bought 100 goats for the gift of the freed shepherd, while the remaining goat is only 5 heads what is the number of goats first?

c. How much money does the Caliph have to give a gift to the shepherd's slave if a goat is priced at $\mathrm{Rp}$ $2,500,000$.

d. Which is the bigger price of 100 goats or the price of an honest slave according to your answer on point a?

Analogy is a technique for the formation of spiritual values through the taking of the existing substance of substance from a social reality that occurs, previous knowledge that has been in the minds of learners or beliefs possessed. For example, will awaken learners to the nature of divine majesty is cheap and wise against His servants through material comparable valuation. The goal besides learners can find the concept of comparable valuation also to be able to be grateful for the blessings of 
Allah swt is granted to Muslims. Starting from the belief of teacher learners can start with a question and a little narrative for example as follows:

What feelings can we offer to Allah Almighty, who has made us as the people of the Prophet who have many virtues? How unfortunate Allah swt to us, our age is shorter than the age of the people before us but every good we do then Allah will multiply ten times as much. But if doing evil then Allah will not multiply our ugliness but the equivalent of his actions, try you read QS. Al-An'am: 160.

Whoever carries good deeds, then for him (reward) ten times his charity; and whoever carries evil deeds then he is not given retaliation but is well-balanced with his wickedness, while they are not even persecuted.

a. If the virtue of a Muslim is expressed by $b$ and the frequency of good deeds done by $r$ can you express the relationship between $\mathrm{b}$ and $\mathrm{r}$ ?

$b$. If price $r$ rises what happens with $b$ and vice versa if price $b$ goes down what happens with $b$ ? That's what's called a comparable ratio.

c. What can you conclude about worth comparisons?

Illustration is a technique of forming spiritual values through concrete, visible, observable, simulated and even played. In the illustrations there are instructions for performing a simulation or practicum activity using visual aids that can illustrate the concepts of mathematics as well as give the spiritual meaning of Islam. For example in this case learners will be made aware of the importance of integrity, cooperation in the goodness as a form of submission to the command of Allah swt through the sum of the different denominations of denominator, as follows:

- Using Cuessionaire rods find the result of

$$
\frac{1}{3}+\frac{1}{2}
$$

- Learners are asked to illustrate the following numbers of Cuessionaire stems:

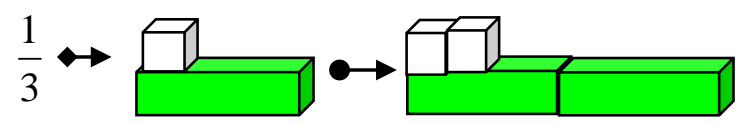

Fig. 1. Exchange 1/3 become 2/6

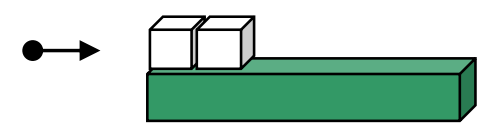

$$
\frac{2}{6}=\frac{1 \times 2}{3 \times 2}
$$

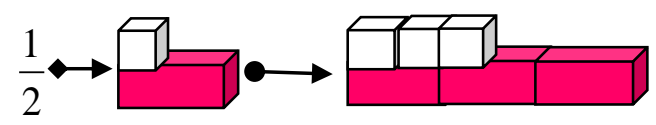

Fig. 2. Excange $1 / 2$ to become $3 / 6$
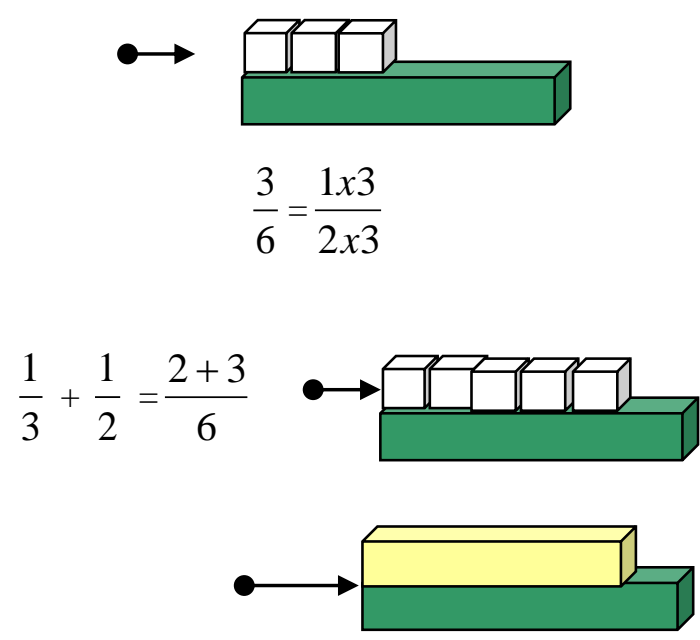

$\frac{5}{6}$

$\frac{1}{3}+\frac{1}{2}=\frac{1 \times 2}{3 \times 2}+\frac{1 \times 3}{2 \times 3}=\frac{2}{6}+\frac{3}{6} \quad \frac{2+3}{6}=\frac{5}{6}$

generally $\frac{a}{b}+\frac{c}{d}=\frac{a d+b c}{b x d}=\frac{a d+b c}{b d}$

The principle of illustration is that the sum operation of two or more denominations whose different denominators can only be executed if the denominator is equalized first. There is an important Islamic spiritual message that can be drawn from this activity that:

"The process of unification of the people must be done through cooperation between two people (groups) or more through the process of equating vision, mission and goals. In Islam this is usually done through consensus mufakat not by voting or majority vote. "

Philosophical is a technique for the formation of spiritual values by using a well-meaningful footing that is stored in symbolic form, whether in the form of numbers, number and language operations in a series of stories. For example will integrate the values 
of Allah's majesty through the introduction of Arabic symbols as follows:

- Take a good look at what symbols are on your right and left palms. In the palm of your hand is written a stamp bearing the Arabic number that is and on your left hand written.

- What is the value of the numbers?

- I $f$ both numbers are summed, what do you think of the number of those two numbers?

- This is what is called "ASMA ULHUSNA" the great names of God Almighty.

Other examples such as learners will be made aware of the majesty of Allah swt as the creator of the universe whose existence is different from its creatures, Allah existed before all existed, and $\mathrm{He}$ existed by Himself. For example this spiritual message will be conveyed through the sum of the original numbers as follows:

Hint: In each of the following figures there are three circles: the core circle, the middle circle and the outer circle. In the core circle has provided each of the numbers 9, 8, 6, and 1. Express the number as the sum of two Original sayaan each located on the middle and outside circle.

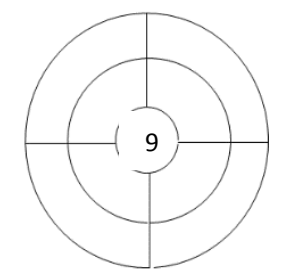

Fig. a

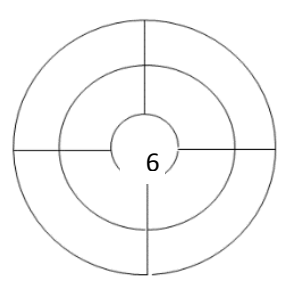

Fig.c

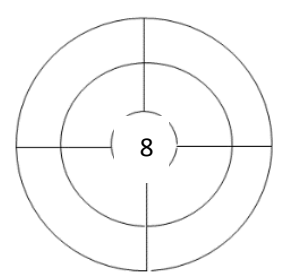

Fig. b

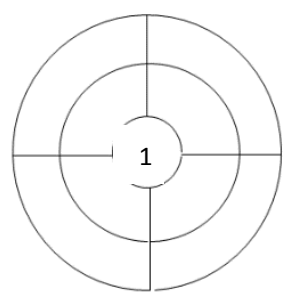

Fig. d a. By summing the two original numbers, by how many ways can you construct the numbers in the image above?

b. From figure a to c you can find the constituent numbers for example $9=2+6,8=3+5,6=1+$ 5 what about the image $\mathrm{d}$, where is the number 1 coming from?

c. What lessons can you learn from the phenomenon?

It turns out there is no number that can compose the number 1 because the existence of number 1 already existed before the other numbers there otherwise the other numbers can be constructed from 1. Ahad (one) is the nature of the Creator who has greatness and privilege, there is no allies for the beginning and end. $\mathrm{He}$ is the one substance whose existence does not exist that precedes and creates. Remember that you are a being whose new existence is preached by Allah and will return to Him. The integration of Islamic spiritual values in the model of mathematics learning is more of a logical syntax, communicating in the solution of mathematical problems to the context of human life that is imbued with Islamic spiritual values. In developing problem-solving skills, learners are encouraged to cooperate, collaborate and share among learners in a learning group. Each group learns to get the Worksheet on a specific subtopic, investigative tasks, and schedule. The tasks of the teachers are (1) to monitor and evaluate the work of each group to maintain the performance and group dynamics during learning by upholding the spiritual values of Islam, (2) to make all learners actively involved in a number of investigation activities and the results of the investigation this can result in a solution to the problem.

In the execution of each model requires a creative method that involves the participation of students. Marsigit (2014: 69) suggests the need for cooperative group tasks, project work and problem solving to foster self-esteem, involvement and mastery; autonomous projects, exploration, problems and investigative work, to foster student creativity, self-direction and engagement through personal relevance; asking questions, pedagogy and assessment models used, is useful for growing critical thinking skills.

At this stage, a learning experience with Value Clarification Technique (VCT) strategy is developed that can help learners to find or determine the value that is considered good in facing a problem through the process of analyzing the values that already exist and embedded in the students. This technique was first introduced by Douglas Superka (1976: 105). Here are some choices of VCT strategies that can be developed in this stage: (1) an evocative approach that learners are encouraged to express their ideas, responses, feelings, openly and freely, (2) a directed, (3) awareness approach that is through a learner's activities given the opportunity to observe and be guided to clarify himself, (4) the moral reasoning approach of the teacher expressing Dilemma to students and memints involved in the dilemma through dialogue.

Furthermore Iyer (2013: 18-19) proposes an approach that can be selected as an alternative to value learning as UNESCO dilates in the development of character education as follows: (1) 
Telling (value development process that enables students to get a clear picture of value from a negated situation, (2) Inculcation (approach towards instilling norms of personal value system), (3) Persuading (the process of convincing students to receive certain values and behaving according to the value received), (4) Modeling (an individual role (5) Role playing, (6) Simulation (learners pretending to be in certain situations to imitate certain values), (7) Problem solving (a linguistic approach that displayed so that students ask them how decisions are taken), (8) Discussion sistuasi, stories, drawings (this technique requires students to explain deng (9) Assess the biography of the big man (this approach uses the life of the great man as subject matter to try to generate / bring good needs and valuable thoughts as a race event), (10) Moralizing (activity restructuring one's social experience through rational analysis), (11) Value clarification (learners release the wealth of students' skills as a process of beliefs to behave in accordance with what they believe).

For example through LKS or LCD impressions of teachers learners are made aware of the spiritual values of Islam that is the importance of a meaningful life in servitude to Allah swt through the material relations of the set, especially subsets. It is expected that through this activity students can find the concept of subsets. The concept of mathematics constructed by analogy of social reality is then generalized in terms of definitions. The selected learning model is CIRI model (Collaborative, Innovative, Reflective and Interactive). Collaborative because they are required to cooperate with each other instead of individual work, Innovative because they are free to improvise their own ideas in their own way, Reflective because they have to think and feel themselves both the logic (intellectual) and the spiritual values contained in the material, and Interactive because they share ideas both inter and between groups. (Kusno, 2013: 31).

The first step: Collaborative, the learners are grouped with the number of 4-5 members of each group in a random way eg sequence from the front seat (its assumtion that student seat is random) students are asked to brandish his finger while mentioning the name of his group with the order of the names of companions of the Prophet. for example one Abubakar, two Umar, three Usman, four Ali and so on. After the group was formed they were asked to see the impressions that teachers have prepared on the LCD as follows:

- Have you ever thought at this moment how many people inhabit this earth?

- Among the inhabitants of this earth how many Muslims?
- Among Muslims how many do the five daily prayers?

- Among those who prayed five times what prayers are in congregation in the mosque?

- Among Muslims who pray in the mosque what istiqomah not takbirotulikhram left behind from the priest?

- Did not Rosululloh remind us:

"Whoever prays for Allah for 40 days during the congregation with the first takbir priest, so writen for him two freedoms namely freedom from the fire of hell and freedom from hypocrisy (HR.Tirmidhi)."

If the population of the earth is declared with the set A, a group of Muslims is expressed by the set B, a group of Muslims who prayed five times is declared with the set $\mathrm{C}$, a group of Muslims who prayed five times done in congregation expressed by $\mathrm{D}$, a group of Muslims who pray the congregation is performed in the mosque declared by E, and a group of Muslims who pray their congregation in the mosque never left behind from takbirotul ikhram priest in succession for 40 declared with F:

- Express the set relation A, B, C, D, E and F in the Venn diagram and give the reason.

- As a faithful servant of God, what will you choose? Why?

Every Muslim must be a resident of the earth, but not every inhabitant of the earth is Muslim. It is stated in the mathematical sentence that the set of Muslims is part of the earth's population or written $\mathrm{B} \subset \mathrm{A}$ and it is read B is a subset of A. Let you explain when the set $\mathrm{P}$ is a subset of $\mathrm{Q}$ ?

The second step: Innovative, each group is asked to discuss the task freely in accordance with the understanding and idea of each. They must share among the members of the group in such a way that it is certain to understand the material from multiple points of view widely and be able to convey their ideas to other groups.

Third step: Reflective, along with the process of teacher discussion around while giving hint, or indirect guidance leading to the answers but giving direction to the thinking especially to the group that is considered less responsive. Besides, it also asks students to reflect on what spiritual messages are contained in the material.

The fourth step: Interactive is to ask the group to present the results of the discussion. To ensure that learners are motivated then the students were motivated with Islamic spiritual values, for example by using the spiritual message of the Prophet Muhammad (saw): 
"Whoever shows good to a people then rewards him for the good of the people who follow him". HR. Muslim.

A group that is willing to move forward hands up, and the teacher chooses to raise his hands first while appreciating with the spiritual message such as this is assabiquunal awwaluun (the forerunner generation). They were asked to go forward with all their members and each member was asked to play a role in presenting the results of his discussion. In this interaction process teachers actively provide their role as facilitators, evaluators and dynamicators to obtain meaningful conclusions for the lives of learners.

\section{References}

Al-Attas, Syed Muhammad Naquib (1989). Islam and the philosophy of science, Kuala Lumpur: ISTAC, .hal -5

Ahmad Rivauzi. (2007). Spiritual Based Education; Study the Thought of Spiritual Education Abdurrauf Singkel in the Book of TanbihalMasyi. (Thesis). Padang: PPs IAIN Imam Bonjol Padang.

Aldarabah, Reham Almohtadi \& Khaled Mohamed. (2014). Islamic spirituality practices (isp) of preschool teachers and its influence on teachers' organizational commitment (TOC) in work place. International journal of educational research and technology. P-ISSN 0976-4089; EISSN 2277-1557. IJERT: Volume 5 December 2014, pp. 68-75

Dalmeri \& Ratono. (2016). Islamic spirituality movement and its implications on social and political ethics in Indonesia. International Journal of Islamic Thought ISSN 2232-1314 Vol. 9: (June) 2016., p. 16

Dinata, (2015). Implementation and constraints of character education are integrated. essay. yogyakarta: Sanata Dharma University, p. 168

Einstein, Robert (1982). Ideas and Opinion. New York. Three Rivers Press, p. 8-9

Fanani; Sholihan \& Karnadi, (2014). Paradigm transformation and its implications on the design of the science curriculum. Collective research report. Semarang: Dipa IAIN Walisongo, p. 51
Giacalone, R; Jurkiewicz, C (2003). Handbook of Workplace Spirituallity and Organizational Performance. New York. M.E. Sharpe, p. 46-48

Grine, Fares \& Mequellati. (2015). Islamic Spirituallity and entrepreneurship. The Journal of happiness \& Well-Being, 2015, 3 (1), p. 41

Haryanto (2014). Building critical awareness through education. Proceeding National Seminar of Faculty of Education, Yogyakarta State University, September 27, 2014. p. 65

Hamza, Isa; \& Janor (2010). Spiritual education development model. Journal Of Islamic and Arabic, Education, 2 (2) - 2010-1-12, p

Hardjana (2009). Religiosity, Religion, and Spirituality. Yogyakarta: Kanisius., P. 64

Huda \& Kartanegara (2015). Islamic spiritual character values of al-zarnǎju's taæ̌clum almutað̌callim. Mediterranean Journal of Social Sciences MCSER Publishing, Rome-Italy Vol 6 No. 4 S2 July 2015, p. 234

Iyer, Ranjani. B. 2013. Value based education: proffesional divelopment vital towars effective integration. IQSR Journal of Research \& Methods in Education (IOSR-JRME) e-ISSN: 2320-7388, p-ISSN: 2320-737X Volume 1, Issue 1 (Jan-Feb 2013), PP 17-20

Kusno. 2013. The Implementation of CIRI (Collaborative, Inovative, Reflective, and Innovative) learning model for the character of education in the mathematics department. Proceeding 1nd AeCon 2013, p. 70

Marsigit. 2014. The Implication of Vigotsky's Work to Mathematics Education. Available at http: //uny.academia.edu.MarsigitHrd. Retrieved 14 April 2016

Miller, J (2005). Holistic Learning and Spirituality In Education. USA: State University Of New York Press, p. 2

Mulyana, Rohmat. (2011). Articulating Value Education. Bandung: Alfabeta.

Nasr, Hossein. (2008). Islamic Spirituality. USA: Routledge., pp. 21-23 
Motha, Jennifer. (2011: 59). Spirituality and Its Relevance For The Contemplative Educator. The Netherlands: Sense Publisher., Page 59

Purwadarminta W.JS. (1999). General Indonesian Dictionary. Jakarta: Balai Pustaka. H. 677.

P4TK. 2011. Roles, functions, objectives and characteristics of school mathematics. Available at http://www.p4tkmatematika.org. accessed May 11, 2016, p. 3

Rusniati (2015). National education and globalization challenges. Scientific Journal Didaktika August 2015, VOL. 16, No. 1. p. 109

Rusdiana (2014). The integration of Islamic religious education with science and technology. Journal.uinsgd. Issue August 2014 Volume VIII No. 2, p. 126

Salafudin. (2015). Mathematical learning is loaded with Islamic values. Journal of Research Vol. 12, November 2015, p. 238.
Superka, D.P., Ahrens, C., Hedstrom, J.E., Ford, L.J. \& Johnson, P.L. (1976). Values Education Sourcebook. Colorado: Social Science Education Consortium, Inc. pp. 105-193

Tanyi R.A (2002: 500). Towards clarification of the meaning of spirituality. Journal of Advance Nursing 39 (5),

p. 500

KDP PPK team (2017). Training Module Strengthening Character Education for Teachers. Available at http://cerdasberkarakter.kemdikbud.go.id, accessed August 10, 2017

Tulaeka, Hamzah et al, (2012). Moral Mysticism. Surabaya: IAIN Press.

Widodo. (2015). The role of mathematics and mathematics education in shaping the character of the nation to face global challenges. Presented in a national seminar of mathematics and mathematics education FKIP Muhammadiyah University Purwokerto, 12 December 2015 